ETO: 811.511.141(497.113)

ORIGINAL SCIENTIFIC PAPER

811.163 .41

$81>373$

DOI: 10.19090/hk.2019.3.106-122

\author{
ANDRIĆ Edit \\ Újvidéki Egyetem, Bölcsészettudományi Kar \\ Magyar Nyelv és Irodalom Tanszék \\ Újvidék, Szerbia \\ andrice@fff.uns.ac.rs
}

\title{
LEXIKAI INTERFERENCIAJELENSÉGEK A VAJDASÁGI MAGYAR NYELVBEN ${ }^{1}$
}

\section{Lexical Interference in the Vojvodinian Variety of Hungarian}

\section{Leksička interferencija u govoru vojvođanskih Mađara}

Az interferencia fogalma a nyelvészetben azt a jelenséget nevezi meg, amikor két érintkező nyelv közül az egyik zavaró hatással van a másikra. Leginkább heterogén nemzeti és nyelvi közösségekben jelentkezik. Kezdetben az anyanyelv befolyásolja negatívan az idegen vagy környezetnyelv elsajátítását, később viszont a második nyelv hat vissza az anyanyelv használatára. Rendkívül fontos, hogy éppen Vajdaságban foglalkozzunk az interferencia jelenségével, és hogy folyamatosan figyeljük tendenciáit. A dolgozat a kisebbségi helyzetben levő vajdasági magyar nyelvet érő interferenciajelenségekröl számol be, különös tekintettel a lexikai hatásokra. Ezúttal nem csak a szerb szavak mértéktelen beáramlásáról, adaptálásáról lesz szó, inkább a frazeológiai egységek tartalmi tükröztetéséről, valamint a már meglevő magyar szólások jelentésbővítéséről a szerb nyelv hatására.

Kulcsszavak: interferencia, lexika, alaki tükrözés, tartalmi tükrözés, frazeológia, magyar nyelv, szerb nyelv

\section{Bevezetés}

A kisebbségi léthelyzetben, heterogén nemzeti közösségekben élő emberek eleve arra vannak utalva, hogy valamilyen szinten kétnyelvüekké váljanak. Hogy ezt a potenciális szituatív lehetőséget milyen mértékben tudják, vagy tudják-e

\footnotetext{
${ }^{1}$ A dolgozat a Tartományi Felsőoktatási és Tudományügyi Titkárság 142-451-2515/2019-01. számú, Interferenciajelenségek a vajdasági magyar nyelvben és irodalomban címü projektum keretében készült.
} 
egyáltalán hasznosítani, az sok mindentől függ. A kétnyelvüség iránti viszonyulást, a kényszerűségként való elfogadását, illetve annak pozitív értékelését befolyásolhatják a konkrét társadalmi viszonyok, a nemzetpolitikai attitüd, a nemzetiségi értelmiség érdekeltsége és aktív angazsáltsága, a személyes pozitív vagy negatív tapasztalatok, a történelmi múlttól és sérelmektől való szabadulás szándéka stb. A kétnyelvüség iránti pozitív viszonyulás csak abban az esetben alakulhat ki, ha tudatosodik bennünk, hogy a környezet nyelvének elsajátítása és magas szintü birtoklása nem okvetlenül jelenti anyanyelvi kompetenciánk visszafejlődését, romlását, sem azt, hogy asszimilációs törekvéseknek engedünk, hanem hogy kétnyelvüségünk folytán is oda tudunk hatni, hogy az nemzetiségi közösségünk hasznára váljon, mert a többség nyelvén is, azon a nyelven, amelyet mindenki megért, tolmácsolni tudjuk érdekeinket, s ezáltal érvényesülni tudunk.

A kétnyelvü beszédmód egyik legfontosabb fogalma az interferencia. Az interferenciának nincs egyöntetúen meghatározott definíciója, az idegen szavak szótára is csak fizikai müszóként tartja számon, ezért az értelmezése eltér a szakirodalomban. Közös vonása ezeknek a szemléleteknek az, hogy egy nyelvnek, vagy nyelvváltozatnak egy másik nyelvre/nyelvváltozatra kifejtett negatív hátását jelöli, szemben a transzferrel, amely pozitív hatást jelent. Már ebből is kiderül, hogy léteznek interlingvális (nyelvek közötti) és intralingvális (nyelvváltozatok közötti) interferenciajelenségek. Először a nyelvelsajátítási elméletek terminusaként jelentkezett, amikor elsősorban az anyanyelv zavaró hatásaként értelmezték az idegen nyelv tanulása során, de ma már a második nyelvnek (legyen az idegen vagy környezeti nyelv) az anyanyelvre történő befolyását is értjük alatta.

Nálunk, a vajdasági magyar közösségben mindkét irányú interferencia jelen van: egyrészt a szerb nyelv tanulását nehezítik a berögződött magyar alaktani és mondatszerkesztési szabályok, másrészt pedig a szerb mint a társadalmi környezet nyelve fejti ki hatását anyanyelvünkre. Ezért van szükség a kontrasztív módszer alkalmazására a tanítás során, hogy a nyelvtanuló minden alkalommal szembe tudja állítani a két nyelv rendszerét, és tudatosan használja azokat.

Az interferenciajelenségeknek többféle osztályozási módja van. Legelterjedtebb a nyelvi szintek alapján történő megkülönböztetésük, mely szerint vannak hangtani, alaktani, lexikai, de a mondatszerkesztésben is megnyilvánuló hatások. Ezeknek száma és előfordulási gyakorisága különböző lehet. Míg a hangtaniak inkább intralingvális jellegüek, addig az interlingvális interferencia leginkább a szókészlet és a mondatszerveződés szintjén érhető tetten. A dolgozat a szerb nyelvnek a vajdasági magyar nyelvre gyakorolt lexikai hatásairól szól. 


\section{Az alaki tükrözés}

A lexikai interferencia legfőképpen a kódkeveredésben és a tükrözésben nyilvánul meg, ezért a lexikai szintủ kódváltás során bekövetkezett alaki tükrözéssel, valamint a tartalmi tükrözéssel foglalkozom. Az ilyen jellegü kutatások a szinkrón nyelvállapotot szokták bemutatni, mivel azonban munkásságom során két ízben kutattam ezt a jelenséget (harmincévnyi időeltolódással), egyfajta diakrón szemléletü következtetéslevonást is megkockáztathatok.

A kutatásokról: először a múlt század nyolcvanas éveiben (1986/87-ben) végeztem korpuszgyüjtést a magiszteri dolgozatomhoz, másodszor pedig két évvel ezelött végeztem egyfajta kontrollgyüjtést. Ennek eredményeképpen jelent meg tavaly a témakörrel foglalkozó könyvem is (Andrić 2018). Továbbá, az utóbbi időben sokat foglalkoztam kontrasztív frazeológiai kutatásokkal, amelyek különösen a tartalmi tükröztetés jelenségéhez szolgáltattak számottevő adatot.

Az alaki tükrözés a szavak eredetét tekintve közvetlen és közvetett lehet. A kultúrszavakra nincs megfelelő kifejezés nyelvünkben. Ilyenkor indokolt a szerb szavak átvétele, azonban többnyire olyan szavak hangzanak el a magyar beszélők megnyilatkozásaiban, amelyekre létezik megfelelő lexikai elem a magyarban, mégis a szerb változatot használják. Még az értelmiség körében is előfordul, hogy megkülönböztető jelleggel tükröztetnek testületi megnevezéseket. Ez leginkább olyankor fordul elő, amikor több szerb terminusnak a magyarban csak egy felel meg. Ilyenek például a szerb veće és a savet szavak, amelyeknek a magyarban a tanács az ekvivalensük. Természetesnek számít, hogy a kommunikáció felgyorsítása és a megnyilatkozás egyértelmübbé tétele ürügyén csak egyszerúen azt mondjuk, hogy meg kell fogalmazni az N. N. vétyének a kérelmünket, vagy a Szávet elfogadta az árjegyzéket. Így pontosan tudjuk, hogy melyik tanácsra gondolunk a konkrét esetben, nem kell hosszadalmasan kifejteni. Hasonló eset áll fenn a szerb komisija, odbor, komitet szavak esetében is, amelyeket a magyarban mind bizottságnak kell fordítani, de akkor a bizottság teljes nevét kell említeni ahhoz, hogy pontosan tudjuk, melyikröl van szó.

Közvetett tükrözés is garmadával előfordul, amikor a nemzetközi idegen szavakat a szerb nyelvben meghonosodott alakjukban és jelentésükben használjuk. Ilyen pl. az akció szó, amely nálunk 'részvény' értelemben is előfordul, vagy az aktus 'okirat, ügyirat, dokumentum' helyett (és nem 'cselekedet, tett', 'ünnepség, szertartás', esetleg 'közösülés', ahogy a magyar idegen szavak szótárában áll), a degradál a 'megaláz, lebecsül' helyett (és nem 'lefokoz'), a

\footnotetext{
${ }^{2}$ Leginkább szakmai vagy tudományos tanács: stručno veće, nastavno-naučno veće...
} 
deklaráció az 'árucímke, használati utasítás' helyett (a magyarban csak 'nyilatkozatot', 'kijelentést', 'bevallást' jelent), a detonáció 'hangtévesztés' helyett éneklés során (nem pedig csak robbanást jelent), deviza 'szállóige' helyett (nem csak külföldi pénznem, valuta), diszpozicióo 'költségvetési rendeltetés/tétel' helyett, dotáció 'támogatás' helyett, esztráda 'szórakoztató jellegü müsorok és résztvevöi' jelentésben, expressz resztorán 'önkiszolgáló étterem' helyett, kompozició '(vonat) szerelvény' helyett stb.

Már a fenti példák alapján is megállapíthatjuk, hogy az alaki tükrözés lehet teljes és részleges: amikor változatlanul vesszük át a szerb szavakat képzőkkel együtt, illetve magyar toldalékokkal látjuk el öket. Ezek a szavak önállóan, vagy egész szerkezetként ékelődhetnek a megnyilatkozásba.

Úgy él, mint bubreg u loju. ${ }^{4}$

Egész nap csak szasztancsizik, aztán navrat nanosz összedob kétlapnyi izvestájt. És akkor 'ugye kobajagi egész nap dolgozott. ${ }^{5}$

Csisztacsicából lett kurirka, és most szolizza a pametomat. ${ }^{6}$

Különbözö tárgykörbe tartozó szavakat tükröztetünk, ez leginkább a konkrét beszédhelyzettől, a beszédtémától függ. Leggyakrabban talán mégis az ételre és italra vonatkozó elnevezések fordulnak elő, de a lakberendezéssel, ruházattal, közszükségleti cikkekkel kapcsolatosakból is sok van, a társadalmi-politikai, valamint az államberendezéssel összefüggő kifejezésekből stb. Szófaj tekintetében a legszámosabb a főnév, de elég sok igét is feljegyeztem, jóval kevesebb melléknevet és állandósult szókapcsolatot. Az utóbbiakból sorolok fel néhányat:

ákobogdá - ha isten is úgy akarja

(ko)bajagi-színleg

bezveze - összevissza

bez brige - ne aggódj, semmi gond,

bogáti - indulatszóként, 'az istenért'

bógtepitá - isten tudja

császná récs - becsület szavamra

\footnotetext{
${ }^{3}$ A magyarban jelenthet intézkedést, utasítást, hajlamot, készséget, hajlandóságot, jókedvet, beosztást.

${ }^{4}$ Mint vese a faggyúban (hal a vízben).

${ }^{5}$ Egész nap gyűléseken van, aztán hủbelebalázs módjára összedob kétlapnyi jelentést. És akkor, úgymond, egész nap dolgozott.

${ }^{6}$ Takarítőnőből lett kifutó, és most okoskodik/játssza az eszét.
} 
$\operatorname{dragics}(k a)$ - indulatszó, 'meglepetés'

(h)ájde de - még hagyján

májkumu - az anyja mindenit

povúci-potégni - nagy nehezen, nagy nehézségek árán

mint grom iz vedrá nébá - mint derült égböl a villámcsapás

málo szutra - sohanapján

zaboga - az isten szerelmére

Talán érdekes megfigyelni, hogyan alakul a szerb szavak használatának száma az adatközlők életkora és neme függvényében. Az alábbi táblázat a közvetlen tükrözések alakulását mutatja a két gyüjtés során. A közvetett tükrözés adatai nincsenek feltüntetve. ${ }^{7}$

\begin{tabular}{|c|c|c|c|c|c|c|}
\hline $\begin{array}{c}\text { Adat- } \\
\text { közlők }\end{array}$ & \multicolumn{2}{|c|}{ Régi gyưjités } & \multicolumn{2}{|c|}{ Újabb gyüjtés } & \multicolumn{2}{|c|}{ Összesen } \\
\hline A & 17 & \multirow{2}{*}{40} & 7 & 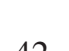 & 24 & \multirow{2}{*}{82} \\
\hline B & 23 & & 35 & & 58 & \\
\hline C & 50 & \multirow{2}{*}{94} & 8 & \multirow{2}{*}{20} & 58 & \multirow{2}{*}{114} \\
\hline D & 44 & & 12 & & 56 & \\
\hline $\mathrm{E}$ & 52 & \multirow{2}{*}{114} & 4 & \multirow{2}{*}{14} & 56 & \multirow{2}{*}{128} \\
\hline $\mathrm{F}$ & 62 & & 10 & & 72 & \\
\hline G & 107 & \multirow{2}{*}{184} & 13 & \multirow{2}{*}{23} & 120 & \multirow{2}{*}{207} \\
\hline $\mathrm{H}$ & 77 & & 10 & & 87 & \\
\hline I & 98 & \multirow{2}{*}{189} & 16 & \multirow{2}{*}{46} & 114 & \multirow{2}{*}{235} \\
\hline $\mathrm{J}$ & 91 & & 30 & & 121 & \\
\hline K & 42 & \multirow{2}{*}{69} & 8 & \multirow{2}{*}{27} & 50 & \multirow{2}{*}{96} \\
\hline $\mathrm{L}$ & 27 & & 19 & & 46 & \\
\hline ML & \multicolumn{2}{|c|}{50} & \multicolumn{2}{|c|}{-} & \multicolumn{2}{|c|}{50} \\
\hline Összesen & \multicolumn{2}{|c|}{740} & \multicolumn{2}{|c|}{172} & \multicolumn{2}{|c|}{912} \\
\hline
\end{tabular}

${ }^{7}$ Az adatközlők kategóriájának jelölése: A - általános iskolás korú lányok, B - általános iskolás korú fiúk, $\mathrm{C}$ - középiskolás lányok, D - középiskolás fiúk, $\mathrm{E}$ - egyetemista korosztályú lányok, $\mathrm{F}$ - egyetemista korosztályú fiúk, $\mathrm{G}$ - fiatal nők, $\mathrm{H}$ - fiatal férfiak, I - középkorú nők, J - középkorú férfiak, $\mathrm{K}$ - idős nők, L - idős férfiak, ML - Matijevics Lajos gyüjtése. 
A fentiekből tehát kiderül, hogy nemi megkülönböztetés nélkül az általános iskolás gyerekek (beleértve a Matijevics gyüjtéséből átvett adatokat) összesen 132 szót tükröztettek, a középiskolások 114-et, az egyetemi hallgatók 128-at, a fiatal nők és férfiak 207-et, a középkorú emberek 235-öt és az idősebbek 96-ot. Ezeket az adatokat azonban fenntartással kell fogadni, mert szituációfüggő eredményekről van szó, annak ellenére, hogy igyekeztem arányosan megválogatni az adatközlők nemét és korosztályát. Az alábbi néhány példa középkorú férfiak és nők beszédében hangzott el nemrégiben.

- Olyan gúzsva van $u p$. $m$. mikó mész kifelé. ${ }^{8}$

- Kiment a magyarokhó, magyar passzusa van. ${ }^{9}$

- Akkó nedáj bozse valami történik. ${ }^{10}$

- A leszonit még rosszabb mind az iverica. ${ }^{11}$

- Vannak ilyen vékony trakák. Csak a traka köllene. ${ }^{12}$

- Ezt a szisztémet még nem próbátam. ${ }^{13}$

- Mindég resztoránba ettem, mésano mészót. ${ }^{14}$

- Mék a lúkába a vámra. ${ }^{15}$

- Szlovénacokka nem lehet. ${ }^{16}$

- Van az itten is a Ruma rászkrsznicán. ${ }^{17}$

- 10-15\% pópuszt van szezonra. ${ }^{18}$

- Sose vettem ki a vignyettát. Én a firmátú kapok... ${ }^{19}$

\footnotetext{
${ }^{8}$ Gúzsva - tömeg. Ebben a megnyilatkozásban káromkodás is előfordul ( $u$ p. $m$.), ami gyakori jelenség, mert nem tünik olyan durvának, ha a szerb alakot használjuk, s inkább csak mint szójárás vagy helyzetmondat jelenik meg, mintegy megfosztva azt trágár jelentésétől.

${ }^{9}$ Passzus - útlevél

${ }^{10} \mathrm{Ne}$ adj' isten!

${ }^{11}$ Leszonit - farostlemez, iverica - forgácslemez

${ }^{12}$ Traka - szalag

${ }^{13}$ Szisztém - rendszer, eljárási mód

${ }^{14}$ Resztorán - étterem, mésano mészo - rostélyos vegyes hús

${ }^{15}$ Lúka - kikötö

${ }^{16}$ Szlovénac - szlovén ember (itt konkrétan szlovén vámos)

${ }^{17}$ Rászkrsznica - útkereszteződés, útelágazás

${ }^{18}$ Pópuszt a szezonra - idényjellegü leárazás

${ }^{19}$ Firma - cég
} 
- Nem tudok emenni a menyácsnicába. ${ }^{20}$

- Mindég kisebb a kursz mind a zvanicsno. ${ }^{21}$

- Köllött csináni kópiát. ${ }^{22}$

- Ugyanaz mind a dozvola. ${ }^{23}$

- Nekem megvan a kvalifikációm. ${ }^{24}$

- Majd ha kapunk karticát. ${ }^{25}$

- Vót prévoz tereta meg saobratyajni própiszi. (vizsgák) ${ }^{26}$

- Azt se szabad obezbedzsénye nélkül. ${ }^{27}$

- Azt mondja, nem tudja, mi a dodatni monitoring. ${ }^{28}$

- Nem dolgozik a bankomat. ${ }^{29}$

- Agenció.... ${ }^{30}$

- Ezek az épületek amiket a NÁTÓ szétbombázott ezek nekik szuvenír, vagy mi? ${ }^{31}$

- Brate mili.... ${ }^{32}$

- Nincsen prakszánk. ${ }^{33}$

- Most ahogy volt ez a procena..$^{34}$

${ }^{20}$ Menyácsnica - pénzváltó

${ }^{21}$ Kursz - árfolyam, zvanicsno - hivatalos

${ }^{22}$ Kópia - fénymásolat

${ }^{23}$ Dozvola - engedély, hajtási jogosítvány

${ }^{24}$ Kvalifikáció - képesítés

${ }^{25}$ Kartica - jegy vagy bankkártya

${ }^{26}$ Prévoz tereta - teherszállítás, szaobratyajni própiszi - közlekedési szabályok

${ }^{27}$ Obezbegyénye - biztonsági eljárás vagy őr

${ }^{28}$ Dodatni monitoring - kiegészítő, pótellenőrzés, felülvizsgálat

${ }^{29}$ Bankomat - bankautomata

${ }^{30}$ Agenció - iroda, ügynökség

${ }^{31}$ Szuvenír - emléktárgy

${ }^{32}$ Brate mili - indulatszóként édes testvér

${ }^{33}$ Praksza - gyakorlat

${ }^{34}$ Procena - becslés 


\section{Tartalmi tükrözés}

A tartalmi tükrözés annyit jelent, hogy egy lexikai egységet elemeire bontva ültetjük át a másik nyelvbe, szó szerinti fordításként vagy szerkezeti másolásként is szokás emlegetni. Ez végbemehet a szó, a szószerkezet, de a mondat szintjén is. Általában világos, motivált képződményekről vagy jelentésátvitelről van szó. Ilyen például, amikor a betegkönyv helyett egészségügyi könyvecskét (zdravstvena knjižica) mondunk, vagy a honvédelem helyett a népvédelem (narodna odbrana), a zsákuta helyett a vakutcát (slepa ulica), de sokszor más átváltási müveletek is előfordulnak tükrözés közben, mint például a túlfordítás: belerúgott a lábával (a láb felesleges, mert rúgni más testrészünkkel nem lehet), épitési telek (elegendő az, hogy telek, mert az mindig építkezésre szánt földterület); illetve az elégtelen kódváltás. A mondatszerkezeti tükrözés nem témája a jelen dolgozatnak, de meg kell említeni, hogy ez utóbbi rendkívül változatos interferenciakészlettel rendelkezik.

\section{A frazeológia tükröztetése}

Frazeológiával foglalkozván újabban felfigyeltem néhány jelenségre, amely eddig elkerülte a figyelmemet. A szóképzés egyik ritkább módját idézte fel bennem az olyan típusú szóláskontamináció, amikor a beszélő memóriafelelevenítő mechanizmusában állnak be gondok, és az egyik szó, illetve kifejezés folytatásában nem a megszokott módon végződik a szólás.

Ilyen alapon jöhettek létre a szinte azonos szerkezetü, csak egy elemeikben különböző, de azonos jelentésủ szólásátvitelek. A beszélő tudja, hogy a nyelvében létezik majdnem azonos kifejezés, de nem ismeri annak teljes alakját, vagy helyette a magyar elem szerb megfelelője jut eszébe:

felfedezi Amerikát ${ }^{35}$ - otkriti Ameriku

öreg, mint a Biblia ${ }^{36}$ - star kao Biblija

megfogja az Isten szakállát ${ }^{37}$ - uhvatiti boga za bradu

hegyeket és völgyeket igér ${ }^{38}$ - obećavati brda i doline, v. kule i gradove se feje, se farka ${ }^{39}$ - bez glave i repa

\footnotetext{
${ }^{35} \mathrm{~A}$ spanyolviasz helyett.

${ }^{36}$ Vén, mint Matuzsálem (v. az országút).

${ }^{37}$ Megfogja az Isten lábát.

${ }^{38}$ Füt-fát ígér.

${ }^{39}$ Se füle, se farka.
} 
halk viz hegyet bont ${ }^{40}$ - tiha voda breg roni

otthagyja a csontjait ${ }^{41}$ - ostaviti svoje kosti

fehér mint a mész ${ }^{42}$ - beo kao kreč

a légyböl lovat csinál $t^{43}$ - od muve činiti/praviti konja

elverte mint az ökröt ${ }^{44}$ - prebiti kao vola u kupusu

szamarat csinált belöle $e^{45}$ - namagarčiti

mindent egy kártyára tettünk fel ${ }^{46}$ - staviti sve na jednu kartu

fogalomnak számit ${ }^{47}$ - biti pojam

Vannak közöttük a monofrazémák csoportjába tartozó példák is, mint az alábbiak:

fehérözvegy $y^{48}$ - bela udovica

sárgacsőrü ${ }^{49}$ - žutokljunac

A fentieknél sokkal ritkább eset az, amikor a két nyelvben a frazéma szerkezete megegyezik, de azok mást (is) jelentenek.

három hónap után lábat kapott ${ }^{50}-$ dobiti $_{n o g} u^{51}$

egyre kapkodta a lábát $t^{52}$ - grabiti nogama ${ }^{53}$

alig jött haza, leesett a lábáról $l^{54}$ - padati s nogu $u^{55}$

${ }^{40}$ Lassú víz partot mos.

${ }^{41}$ Otthagyja a fogát.

${ }^{42} \mathrm{Fal}$ helyett.

${ }^{43}$ Elefánt (v. a bolhából elefántot) helyett.

${ }^{44} \mathrm{~A}$ lovat helyett.

${ }^{45}$ Lóvá tette.

${ }^{46}$ Mindent egy lapra tesz fel valaki.

${ }^{47}$ Nagy tekintélynek örvend.

${ }^{48}$ Szalmaözvegy.

${ }^{49}$ Zöldfülü.

${ }^{50}$ Eltünik (lába kel) vagy megerösödik, erőre kap (talpra áll).

${ }^{51}$ Kirúgták.

${ }^{52}$ Táncol (vö. szedi a lábát/kapkodja a fejét).

53 Siet.

${ }^{54}$ Fekvő beteg lett.

${ }^{55}$ Nagyon kifárad, kimerül a munkától. 
nem tegnapi gyerek ö se ${ }^{56}-$ ne biti od juče

ugyan, csak füstöt árul ${ }^{57}$ - prodavati dim

jó mint a jó napot ${ }^{58}$ - dobar kao dobar dan

Nálunk sok helyütt előfordul a lovon van ${ }^{59}$ kifejezés a biti na konju szerb frazéma tükörfordításaként, éspedig a nyeregben érzi magát szólás jelentésében, bár a szerb és az utóbbi magyar szemantikája nem teljesen fedi egymást. A szerbben azt jelenti, hogy 'nehézségek után kedvező helyzetbe kerül', míg a magyar frazéma szerint 'biztos a sikerben, abban, hogy eléri célját'. Mivel azonban elterjedtsége igen széles körü, ezért tájnyelvi jellegre is gyanakodhatunk, intralingvális interferenciára, vagy pedig egy régen átvett szerb tükröztetésre.

A túlzottan takarékos, fukar, garasoskodó emberre a szerbben azt szokás mondani, hogy biti tvrde ruke, aminek a magyarban a szükmarkú felelne meg, de gyakran előfordul nálunk a keménykezü kifejezés is a fenti értelemben, holott az a magyarban határozott, szigorú, kíméletlenül erélyes embert jellemez. Ha valaki lyukas kezü, illetve valakinek lyukas a keze, azt jelenti, hogy ügyetlen, a labda mindig kiesik a kezéből játék közben, de a szerb imati šuplje ruke (amely a magyar példa formális ekvivalense) hatására a pazarló, költekező emberre is vonatkoztathatjuk.

Hasonló módon a gvozdena ruka is megtéveszti az itteni beszélőt, mert az a szerbben erősen fegyelmező embert jelöli, míg a magyar formális ekvivalense a vaskezü 'erős, izmos karú férfit'.

Amikor azt szeretnénk kifejezni, hogy munka közben valami nem hozzáférhetö, olyan fekvése van, hogy nem lehet megközelíteni, a szerb ne biti na ruku hatására a nem áll a kezére alakot használjuk, nem ügyelve arra, hogy ennek a magyar szólásnak a magyarban más az értelme. Azt jelenti, hogy az illető ügyetlen valamely kétkezi munkában.

Ha vkinek hosszú keze van, az nagy hatalommal, jó összeköttetésekkel rendelkezik, vagy pedig olyan személy, akinek bosszúja elől nehéz kitérni, a szerb imati duge/dugačke ruke analógiájára azonban Vajdaságban a tolvajokra is vonatkoztatjuk.

Ehhez még adjuk hozzá a Papp György gyüjtéséből eredő példákat! Az egyik órán felkaptam a fejem, amikor ezt az általa feljegyzett szólást említette: jössz

\footnotetext{
${ }^{56}$ A mai helyett.

${ }^{57}$ Hazudik, csal, ámít (ködösít).

58 Jó, mint egy falat kenyér.

${ }^{59}$ Így nem található meg egyik szólásgyüjteményünkben sem.
} 
te még, mint a fehér tulipán. ${ }^{60}$ Ezt ugyanis nagy elöszeretettel használtuk mi is szerb megnyilatkozásaink során, de addig nem hallottam, hogy a vajdasági magyarok beszédében is előfordult volna a kisangyallal való példálózás helyett. ${ }^{61}$

Íme még néhány példa:

hiányzik egy deszkája ${ }^{62}$ - fali kome daska u glavi

tiszta, mint a könnycsepp ${ }^{63}$ - čist ko suza

minden levesben kapor ${ }^{64}$ - biti u svakoj čorbi mirođija

a vastagabb végét húzza ${ }^{65}$ - izvući deblji kraj

orvosságnak sincs belöle ${ }^{66}$ - nemati ni za lek

ki az ördöggel tököt ültet, a fejéhez verik ${ }^{67}$ - ko s đavolom tikve sadi, o glavu ти se obijaju

a tapétán van ${ }^{68}$ - biti na tapetu

lábon van ${ }^{69}$ - biti na nogama

a feje tetején jön ki vmi $i^{70}$ - izaći na vrh glave

fontos karika a láncban ${ }^{71}$ - važna karika u lancu

az egyik szemére vak, a másikra nem lát ${ }^{72}$ - na jedno oko ćorav, a na drugo ne vidi

eldobja a kanalat ${ }^{73}$ - baciti kašiku

\footnotetext{
${ }^{60}$ Kao bela lala tükörfordításaként.

${ }^{61}$ Jössz te még erre mint a kisangyal.

${ }^{62}$ Hiányzik egy kereke helyett.

${ }^{63}$ Arany.

${ }^{64}$ Minden lében kanál.

${ }^{65}$ A rövidebbet húzza.

${ }^{66}$ Mutatóba sincs.

${ }^{67}$ Aki korpa közé keveredik, megeszik a disznók.

${ }^{68}$ Teritéken van.

${ }^{69}$ Talpon van.

${ }^{70}$ A könyökén jön ki.

${ }^{71}$ Fontos láncszem.

72 Vö. egyik füle bal, a másik nem hall.

${ }^{73}$ Meghal.
} 
nekünk is van versenylovunk $k^{74}$ - i mi konja za trku imamo átlépi a küszöbö̈t $t^{75}$ - prekoračiti prag.

Arról, hogy mennyire elterjedt jelenségről van szó, az is tanúskodik, hogy neves, gyakorlott fordítóink fordításában is előfordulnak a frazémák tartalmi tükröztetései. Idézek néhányat Csuka Zoltán munkájából:

[...] bez žive duše $e^{76}$ (Andrić, Na Drini ćuprija 341).

[...] élö lélek nélkül (Csuka, Híd a Drinán 414).

[...] puni su para kao šipak ${ }^{77}$ (Andrić, Na Drini ćuprija 16).

[...] tele vannak pénzzel, mint a csipkerózsabokor virággal (Csuka, Híd a Drinán 23).

[...] stvar treba uzeti i platiti ili „,poljubiti pa ostaviti” (Andrić, Travnička hronika 248).

[...] a holmit át kell venni és fizetni, vagy pedig „megcsókolni és otthagy-

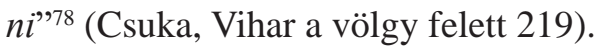

[...] jači konja jaše, a slabiji pješke kasa (Andrić, Omerpaša Latas 88).

[...] az erösebb lóra ül, a gyengébb meg kutyagol (Csuka, Omér pasa 127).

$\mathrm{Tu}$, kao što je davno rečeno, stolica stolici dobra ne misli, a kamoli čovek čoveku (Andrić, Omerpaša Latas 166).

Ahogyan a régi mondás tartja: szék a székröl jól nem vélekedik, hát még ember az emberröl (Csuka, Omér pasa 212).

[...] a posle bi se, kao ekser u ćuftetu, našao njegov vajni pištolj u njemu (Andrić, Omerpaša Latas 184).

[...] és mint szeget a gombócban úgy találják meg benne a pisztolyát (Csuka, Omér pasa 237).

[...] o kome nisu ništa znali, osim da je ,postao težak zemlji “ [...] (Andrić, Travnička hronika 429).

[...] akiröl csak annyit tudtak, hogy ,,nehéz lett a földnek [...] (Csuka, Vihar a völgy felett 381).

\footnotetext{
${ }^{74}$ Az én kardom se bodzafa.

75 Túllépi a határt.

${ }^{76}$ Sehol egy árva lélek.

77 Felveti öket a pénz.

${ }^{78}$ A magyarban csak az ételre vonatkoztatva mondhatjuk, ha nem tetszik, hagyd ott.
} 


\section{A lexikai interferencia oka}

Erdős Gábor az Újabb jelentésváltozások az ifjúsági nyelvben című munkájában (Erdős 1988) felsorolja az idegen szavak használatának okait. Véleményem szerint azok nemcsak az ifjúsági nyelvre vonatkoznak, hanem egyéb nyelvcsoportokra és -rétegekre is érvényesek, és nemcsak az idegen szavakra, hanem általában az alaki tükrözésre. Szerinte az egyén azért használja az idegen szavakat, hogy:

- csökkentse a beszélgetés ünnepélyességét,

- megfeleljen a hallgatóság müveltségi színvonalának,

- szolidaritás kifejezésére, jelezze a barátság fokát vagy a beszélők közeli viszonyát, kifejezze az összetartozás érzését,

- megkönnyítse a társadalmi érintkezést,

- kifejezze a csoportidentitást, csoporthoz való tartozást,

- titkosítson, ne értse meg a környezete,

- elkerülje a közhelyeket,

- tömör legyen és érthető,

- lekösse a hallgatóság figyelmét,

- minél megkapóbb legyen a beszéde.

Tegyük hozzá, hogy az említetteken kívül szerintünk az alaki tükrözés oka lehet még:

- a megjelent új eszközök, tárgyak, fogalmak megnevezésére való törekvés,

- valamilyen forrás pontos idézésének szándéka,

- a szakmai gőg, sznobizmus, az elzárkózás szándéka,

- a megfelelö müveltség hiánya,

- az utánzás szándéka,

- bizonyos személyekkel, sztárokkal való azonosulási törekvés,

- a beszélő tudatlansága (nem ismeri pontosan a szó jelentését, ezért nem tudja mivel helyettesíteni az anyanyelvén),

- nem jut eszébe, és nem is törekszik arra, hogy felidézze emlékezetében a megfelelö kifejezést. 
Ezek, mint látjuk, mind szándékos döntések során elkövetett tükrözések, tudatosan alkalmazza öket a beszélő. Néha viszont nem tudatos döntés következménye az alaki tükrözés, ilyenkor leginkább az igénytelen nyelvhasználat, a nyelvi fegyelmezetlenség és az önkontroll hiánya járul hozzá megjelenéséhez, esetleg az, hogy nincs tudatában, miszerint a tükröztetett szónak van egyéb megfelelöje az anyanyelvén.

\section{Zárógondolatok}

A szerb lexikai elemek beáramlása szinte korlátlan méreteket ölthet, s ez egyrészt a nyelvhasználó mikroközösség konkrét homogenitásától, másrészt viszont magának a nyelvhasználónak az igényességétől függ. Vajdaságban egy rendhagyó tendenciának vagyunk szemtanúi, amely a nemzetiségi közösségek mind kifejezettebb elszigetelődésében nyilvánul meg. A kilencvenes évektől az emberek befelé fordulnak, nem hajlandók érintkezni a másik nemzetiség képviselőivel. Ez oda vezetett, hogy a testvériség-egység hangoztatta eszmék teljesen kivesztek, alig van rá példa, hogy a többségi és a kisebbségi képviselők együttélése nyilvánulna meg, s mindinkább az egymással nem kommunikálók egymás mellett élése hódít teret. Már nem fontos, hogy megértsük egymást, nem fontos, hogy megtanuljuk egymás nyelvét. Ez talán a magyarok részéről egyfajta revansizmus eredménye, felmerül a kérdés, hogy mi célból tanulják meg a szerb nyelvet, ha a szerbek nem mutatnak semmilyen szándékot a magyar nyelv tanulása iránt. Ez hosszú távon oda vezet, hogy a Szerbiában hiányos szerb nyelvtudása miatt érvényesülni nem tudó honfitársaink kivándorolnak, vagy olyan megoldást találnak, ahol nincs szükségük a szerb nyelvtudásra, s ezzel önkéntes elszigeteltségbe vonulnak. S ez a helyzet annak a konklúziónak a levonását feltételezné, hogy az említett helyzet anyanyelvünk megtisztulásához vezet. De ez a feltételezés nem teljesen igazolódik be, mert az utóbbi évtizedben kiderült, hogy még az olyan vajdasági magyarok megnyilatkozásában is fellelhetők a szerb szavak és a szerb nyelvre jellemző fogalmazásmód tükröztetésének nyomai, akik nem beszélik a többség nyelvét. Ez tehát egy megállíthatatlan folyamat, amely ellen nem úgy kell harcolni, hogy ne tanuljuk meg társadalmi környezetünk nyelvét - mondván, hogy ennek semmi hasznát nem látjuk -, hanem pont ezzel ellenkező meggondolásból: kontrasztív módszerekkel kell viszonyulni a szerb nyelv tanulásához, és ugyanakkor az anyanyelvünk ápolásához is, mert a különbségek tudatosításával, a megfelelő szókincs begyakorlásával anyanyelvünk helyesebb használatához jutunk el. 
A lexikai interferencia módja kevésbé, ám a beáramló elemek jellegében tetten érhető a két gyüjtés közötti különbség. A legnagyobb változás a társadalmi-politikai terminológiában tapasztalható. Ugyanis a társadalmi berendezés megváltozásával elavultak a múlt század 70-es éveiben keletkezett kifejezések, amelyek az önigazgatási szocialista államforma terminusait képezték, és csak Jugoszláviára voltak jellemzőek, időközben viszont a piacgazdálkodási és az európai integrációval kapcsolatos kifejezések, időszerű társadalmi-politikai szavak kezdtek beáramlani szerb közvetítéssel.

Ezenfelül az utóbbi évtizedben nagyobb mértékben jelentkeznek a megkövesedett szókapcsolatok, hosszabb frazeológiai egységek a vajdasági magyarok megnyilatkozásaiban.

\section{Irodalom}

Andrić Edit. 1995. A szerb nyelvnek a vajdasági magyar nyelvre gyakorolt hatása. Kétnyelvüség és magyar nyelvhasználat: A 6. élönyelvi konferencia elöadásai. 235-245. Budapest: MTA Nyelvtudományi Intézetének Élőnyelvi Osztálya.

Andrić, Edita. 1989a. Posredne i neposredne pozajmljenice u govoru novosadskih

Mađara. O leksičkim pozajmljenicama: Zbornik radova sa naučnog skupa Strane reči i izrazi u srpskom jeziku sa osvrtom na isti problem u jezicima nacionalnih manjina. 397-403. Subotica: Gradska biblioteka Subotica i Institut za srpski jezik Srpske akademije nauka i umetnosti.

Andrić Edita. 1989b. Srpskohrvatske reči i izrazi u rečniku vojvođanskih Mađara. Zbornik radova 5. Kongresa društava za uporednu gramatiku Jugoslavije. 628-633. Ljubljana: Zveza društev za uporabno jezikoslovje Jugoslavije.

Andrić, Edit. 2000. Közvetlen alaki tükrözés az újvidéki magyarok nyelvhasználatában. Nyelvek és kultúrák érintkezése a Kárpát-medencében: 10. élönyelvi konferencia. 11-16. Budapest: MTA Nyelvtudományi Intézetének Élőnyelvi Osztálya.

Andrić Edit. 2002. Szerb lexikai hatások a vajdasági magyar nyelvben. Iskolakultúra, 12 (10): 72-76.

Andrić Edit. 2004. A vajdasági magyar gyerekek nyelvhasználatában tapasztalható környezetnyelvi hatásokról. Nyelvvesztés, nyelvjárásvesztés, nyelvcsere, szerk. P. Lakatos Ilona és T. Károlyi Margit. 153-162. Budapest: Tinta Könyvkiadó.

Andrić Edit. 2010. Az idegen szavak adaptálása a magyar és a szerb nyelvben. Hungarológiai Közlemények 41 (2): 53-63.

Andric Edit. 2018. Alaki tükrözés az újvidéki magyar nyelvhasználatban. BeauBasin: GlobeEdit.

Andrić, Ivo. 1958. Travnička hronika: Konsulska vremena. Beograd: Svjetlost-Prosveta. 
Andrić, Ivo. 1962. Elátkozott udvar. In Ivo Andrić válogatott müvei III. Ford. Csuka Zoltán. Novi Sad: Forum Könyvkiadó.

Andrić, Ivo. 1962. Prokleta avlija. Beograd: Evro-Giunti.

Andrić, Ivo. 1962a. Hid a Drinán. Ford. Csuka Zoltán. Novi Sad: Forum.

Andrić, Ivo. 1962b. Na Drini ćuprija. Zagreb: Izdavačko knjižarsko preduzeće Mladost.

Andrić, Ivo. 1981. Omerpaša Latas: Sabrana dela Ive Andrića. Knjiga petnaesta.

Udruženi izdavači Beograd: Prosveta, Zagreb: Mladost, Sarajevo: Svjetlost, Ljubljana: Državna založba Slovenije, Skopje: Misla, Titograd: Pobjeda.

Andrić, Ivo. 1983. Omér pasa. Ford. Csuka Zoltán. Budapest: Európa Könyvkiadó.

Ándrics Ivo. 1956. Vihar a völgy felett: Travniki krónika. Ford. Csuka Zoltán. Budapest: Új Magyar Könyvkiadó.

Erdős Gábor. 1988. Újabb jelentésváltozások az ifjúsági nyelvben. Magyar Nyelvőr 2. 143-148.

Matijevics Lajos. 1972. A vajdasági magyar diáknyelv. Újvidék: Magyar Nyelv, Irodalom és Hungarológiai Kutatások Intézete.

Vukov Raffai Éva. 2012. Az örökíró, a hémijszka és ami körülöttük van. Szabadka: Életjel.

\section{LEXICAL INTERFERENCE IN THE VOJVODINIAN VARIETY OF HUNGARIAN}

The concept of interference in linguistics refers to the phenomenon of one of two contact languages having a disturbing effect on the other. It is most common in heterogeneous national and linguistic communities. In the beginning it is the mother tongue which has a negative influence on the acquisition of the foreign or environmental language, whereas later the second language affects the use of the mother tongue. It is of utmost importance to address the issue of interference in Vojvodina and to monitor its tendencies. The paper presents interference phenomena affecting Hungarian as a minority language in Vojvodina, with special regard to lexical influences. This time it does not only tackle the issue of the excessive inflow and adaptation of Serbian words, but rather looks into the calquing of phraseological units and the extension of the meaning of the already existing Hungarian idiomatic expressions under Serbian language influence.

Keywords: interference, lexis, calque, phraseology, Hungarian, Serbian

\section{LEKSIČKA INTERFERENCIJA U GOVORU VOJVOĐANSKIH MAĐARA}

Pojam interferencije u lingvistici pokriva pojavu koja uzrokuje mešanje jezika, kada jedan od dva jezika u kontaktu negativno utiče na usvajanje ili korišćenje drugog. 
Najčešće se javlja u heterogenim nacionalnim i jezičkim sredinama. U početku maternji jezik utiče na usvajanje drugog jezika a zatim i drugi jezik može imati negativni upliv na maternji jezik. Istraživanje jezičke interferencije je istaknuta naučna disciplina, koja poseduje značajne rezultate. Međutim, predmet njenog izučavanja, sâm jezik se konstantno menja, a menjaju se i jezički uticaji, kako po karakteru, tako i po intenzitetu. Izuzetno je važno da se u multijezičkoj i multinacionalnoj sredini kao što je Vojvodina, vrše stalna istraživanja u vezi sa ovom pojavom, koji će ukazati na tendencije i najnovije stanje u jeziku. Rad se bavi uticajem srpskog jezika na manjinsku varijantu mađarskog u Vojvodini, sa posebnim osvrtom na leksikolške pozajmljenice, a kalkove ali i na uticaj na nivou frazeologije.

Ključne reči: interferencija, leksika, pozajmljenice, kalkovi, frazeologija, mađarski jezik, srpski jezik 